\title{
Mandibular Measurements for Sex and Age Estimation in Brazilian Sampling
}

\section{Mjerenja mandibule radi procjene spola i dobi na brazilskom uzorku}

\author{
${ }^{1}$ USP - University of São Paulo, Ribeirão Preto Medical School, Pathology and Legal Medicine Graduation Program. PhD Student (Forensic \\ Odontology), Brazil \\ Medicinski fakultet Ribeirão Preto - Program patologije i forenzičke medicine (postdiplomant Forenzičke odontologije), Sveučilišta São \\ Paulo, Brazil \\ 2 USP - University of São Paulo, School of Dentistry of Ribeirão Preto, Brazil \\ Stomatološki fakultet Ribeirão Preto Sveučilišta São Paulo, Brazil \\ ${ }^{3}$ USP - University of São Paulo, School of Dentistry of Ribeirão Preto, Brazil. Associate Professor (Forensic Odontology) \\ Stomatološki fakultet Ribeirão Preto Sveučilišta São Paulo, Brazil
}

\section{Abstract}

Objective: The present study aimed to evaluate the possibility of sex and age estimation in a Brazilian sample, using the following five mandibular measurements: coronoid height, gonial angle, bigonial distance, ramus height, maximum length. Material and methods: In total, 103 mandibles were measured, 53 female and 50 male, grouped according to the age in 5 different groups. Two different observers performed all these measurements. For statistical analysis, one-way ANOVA was used with a significance level of $5 \%$ to verify if the mandibular measurements were related to age. The Student $t$-test was used for comparisons between the sex samples. Eighty three samples were used to develop a logistic regression model. The intra-observer and inter-observer differences were evaluated using the Kappa coefficient. Results: The sex differences were statistically significant in all the variables, and all of them were larger in men, apart from the variable related to the gonial angle (GA), which was larger in women. For the logistic regression formula, the variables used were: bigonial distance and mandibular ramus, with $90 \%$ accuracy. For age, the measurements did not show a pattern. The inter and intra-observer values were greater than 0.85 . Conclusion: In conclusion, it is possible to estimate sex using mandibular measurements, but it is not recommended to use these measurements for age estimation.
Received: April 10, 2020

Accepted: July 3, 2020

Address for correspondence Julia Gabriela Dietrichkeit Pereira University of São Paulo, Ribeirão Preto Medical School Phone: +55 (19) 984060244 juliadie@usp.br

Key words

Forensic Dentistry; Sex Determination by Skeleton; Age Determination by Skeleton; Mandible; Measurements

\section{Introduction}

The identification of unknown human remains in cases of putrefaction, skeletonization or mutilation is common in forensic practice $(1,2)$, and in these cases, secondary methods, such as the establishment of an anthropological profile, are useful and important (3), through the sex, age, ancestry, and stature estimation, among other parameters of forensic interest. $(3,4)$

Sex is highly important for forensic purposes, mainly because it is necessary to estimate other anthropological parameters. $(4,5)$ There are different methodologies for estimation, which involve analyses of teeth and bones.(6-9) Several authors have studied the mandible for sex and age estimation, mainly because it is robust and protected by the facial musculature, making it easier to be found intact. (10)

Additionally the adult mandible can be used to estimate sex with a high degree of accuracy $(5,7)$, the average values of mandibular measurements are larger for men than for wom-

\section{Uvod}

Identifikacija nepoznatih ljudskih ostataka u slučaju raspada ili sakaćenja uobičajena je u forenzičkoj praksi $(1,2)$, a u tim su slučajevima korisne i važne sekundarne metode, poput uspostavljanja antropološkog profila (3) putem spola, dobi, roda i stasa, među ostalim parametrima od forenzičkog interesa $(3,4)$.

Spol je vrlo važan za forenzičke svrhe, uglavnom zato što je potreban za procjenu drugih antropoloških parametara (4, 5). Postoje različite metodologije za procjenu koje uključuju analizu zuba i kostiju $(6-9)$. Nekoliko autora proučavalo je mandibulu za procjenu spola i dobi, uglavnom zbog toga što je robusna i zaštićena muskulaturom lica, što omogućuje da ostane intaktna (10).

Uz to, mandibula odraslih može se upotrijebiti za procjenu spola $s$ visokim stupnjem točnosti $(5,7)$, a prosječne vrijednosti mjerenja veće su kod muškaraca negoli kod žena (5, $7,11)$. Kada se proučava odnos gonijalnog kuta i spola, neki 
en. $(5,7,11)$ When studying the relationship between the gonial angle and sex, some authors observed that the mean value is larger in women than it is in men. $(11,12)$ Results obtained in several studies showed that the mandibular ramus and the coronoid height have a high discriminatory power for each sex, and can be used for sexual differentiation. $(5,6,8)$

Usually methods of age estimation involve bone and dental analysis.(13-16) Bone measurements have been very useful in these cases, because they are fast and simple to apply. The mandibular ramus is generally intact when identification is required, and has therefore been the subject of much research to estimate age.(17) The gonial angle changes during life, at birth being rather obtuse, then decreasing as one grows up, and increasing again in old age.(18) During growth, the mandibular ramus increases more in height than the mandibular body in length, making the angle more acute. $(18,19)$

There is a scientific consensus that genetic influences skeletal features, and because of that the miscegenation presented in Brazil makes difficult to estimate age and sex based on international measurements and methodologies, since they were often for European populations. $(6,8,10)$ It is very important that each population have their own measurements and formula to estimate age and sex, $(6,8,10)$ validating or creating methods for Brazilian population. Thinking in this importance, the present study aimed to evaluate sex and age estimation in a Brazilian sample, using mandibular measurements.

\section{Material and methods}

The study was approved by the Ethics Committee on Research under number CAAE: 50415215.0.0000.5419, fulfilling all the requirements of the Brazilian Resolution 466/12. (20)

In total, 103 mandibles were measured, 53 female and 50 male, from the Bone Museum of the Department of Social Dentistry (UNICAMP, Piracicaba Dental School). This museum consists of a contemporary sample. The ancestry is difficult to estimate since the population of Brazil is heterogeneous and mixed. Only mandibles in good conditions were included: mandibles without fractures and with previous records about sex and age. Mandibular bones with presence of trauma, malformation, bone lesions or deformities that did not provide a complete mandible were excluded, as well as the ones which had no prior record of sex and age.

The following five measurements were used: coronoid height, gonial angle, bigonial distance, ramus height and maximum length. All these measurements were performed by two observers, without access of the data from the skeletons (age and sex), and without talking to each other. The measurements were repeated, for both observers, a month after the first measurement, in $30 \%$ of the sample.

The measurements were performed in some specific landmarks of the mandible, based on the book "Human Osteology" (21). The measurement of the coronoid height process was performed using the Coronion $(\mathrm{Cr})$ - the point at the tip of the coronoid process of the mandible, and the Gonion (Go) - point along the rounded posteroinferior corner of the mandible, between the ramus and the body, as can be seen in su autori zapazili da je srednja vrijednost veća kod žena negoli kod muškaraca $(11,12)$. Rezultati dobiveni u nekoliko istraživanja pokazali su da ramus mandibule i visina koronoida imaju visoku diskriminacijsku snagu za oba spola i mogu se koristiti za spolno razlikovanje $(5,6,8)$.

Obično metode procjene dobi uključuju analizu kostiju i zuba (13 - 16). Mjerenja na kostima u tim su slučajevima vrlo korisna jer su brza i jednostavna za primjenu. Ramus mandibule općenito je intaktan te je stoga bio predmetom mnogih istraživanja u kojima se procjenjivala dob (17). Gonijalni kut mijenja se tijekom života - pri rođenju je prilično naglašen, a smanjuje se kako osoba raste i ponovno se povećava u starosti (18). Tijekom rasta ramus mandibule povećava se više u visinu negoli u dužinu tijela mandibule te čini kut oštrijim $(18,19)$.

Postoji znanstveni konsenzus da genetika utječe na koštana obilježja, pa zbog toga miješanje rasa u Brazilu otežava procjenu dobi i spola na temelju međunarodnih mjerenja i metodologija jer su one često bile namijenjene za europsku populaciju $(6,8,10)$. Vrlo je važno da svaka populacija ima vlastita mjerenja i formule za procjenu dobi i spola $(6,8,10)$ na temelju kojih se mogu potvrditi ili stvoriti metode za brazilsku populaciju. Imajući to na umu, cilj ovog istraživanja bio je, koristeći se mjerenjem mandibule, procijeniti spol i dob u brazilskom uzorku.

\section{Materijal i metode}

Istraživanje je odobrilo Etičko povjerenstvo za istraživanja pod brojem CAAE: 50415215.0.0000.5419 i ispunjavalo je sve zahtjeve Brazilske rezolucije 466/12 (20).

Ukupno su izmjerene 103 mandibule - 53 ženskih i 50 muških iz Muzeja kostiju Odjela za socijalnu stomatologiju (UNICAMP, Stomatološka škola Piracicaba). U tom su muzeju suvremeni uzorci. Podrijetlo je teško procijeniti s obzirom na to da je stanovništvo Brazila raznoliko i miješano. Uključene su samo mandibule u dobrom stanju - dakle, donje čeljusti bez prijeloma i sa zapisima o spolu i dobi. Mandibularne kosti s traumama, malformacijama, lezijama ili deformacijama bile su isključene, kao i kosti za koje se sa sigurnošću nisu znali spol i dob.

Obavljeno je sljedećih pet mjerenja: visina koronoida, gonaijalni kut, bigonijalna udaljenost, visina ramusa i maksimalna duljina. Sve su to učinila dva promatrača, bez pristupa podatcima o kosturu (dob i spol) i bez međusobnog razgovora. Oba promatrača ponovila su mjerenja mjesec dana nakon prvog mjerenja na $30 \%$ uzoraka.

Mjerenja su provedena na nekim specifičnim orijentacijskim točkama mandibule temeljenima na knjizi Ljudska osteologija (21). Mjerenje visine koronoida obavljeno je izmedu točaka coronion (Cr) - točke na vrhu koronoidnog nastavka mandibule i gonion (Go) - točke duž zaobljenoga posteroinferiornog ugla mandibule, između ramusa i tijela, kao što se može vidjeti na slici 1. A. Gonijalni kut (GA) nastaje sjecištem tijela i ramusa mandibule, kako je istaknuto na slici 1. B. Mjerenje bigonijalne udaljenosti provedeno je između točaka gonion (Go) na objema stranama, kao što je prikazano 
Figure 1-A. The gonial angle (GA) is formed by the intersection between the mandibular body and the mandibular ramus, as highlighted in Figure 1-B. The measurement of bigonial distance was taken between the two Gonion (Go) points on both sides, as observed in Figure 1-C. The measurement of the mandible ramus height was performed using the Condylion superior $(\mathrm{Co})$ - the most superior point on the mandibular condyle, and the Gonion (Go), as can be seen in Figure 1-D. And the measurement of the mandible maximum length was performed using the Condylion (Co), and the Pogonion $(\mathrm{Pg})$ - most anterior midline point of the chin of the mandible, represented in Figure 1-E.

All distances, with the exception of the gonial angle, were measured with the aid of a $0.1 \mathrm{~mm}$ resolution digital caliper and $+/-0.1 \mathrm{~mm}$ accuracy of the Western ${ }^{\mathrm{TM}}$ brand (Etilux ${ }^{\mathrm{TM}}$, São Paulo, Brazil) showing the measurement performed in millimeters. For the determination of the gonial angle, a $180^{\circ}$ protractor was used in such a way that the protractor ruler touched the base of the mandible, and the degree marker was tangent to the posterior edge of the mandibular ramus, thus finding the value of the angle.

The mandibles were grouped according to age: G1: 0-20 years; G2: 21-40 years; G3: 41-60 years; G4: 61-80 years; G5: 80-100 years, regardless of sex. The sample size of the groups was: 4, 24, 29, 35, 11 samples, respectively.

For statistical analysis, the one-way ANOVA was performed, with a 5\% significance level to verify if the mandibular measurements were related to age. The Student t-test was applied for comparisons between the sex samples. These tests were performed using Graphpad Prism Software version 7.01 for Windows (GraphPad ${ }^{\text {Tx }}$, La Jolla, California, USA). Both tests were run on unpaired samples. A logistic regression model was developed using 83 samples which were chosen randomly, and then, 20 measurements were used for testing this model. A stepwise automatic selection was used for choosing the best measurements for sex estimation. The intra-observer and inter-observer differences were evaluated for each measurement performed on the mandibles by the intra-class correlation coefficient (ICC), using the Kappa coefficient. na slici 1. C. Mjerenje visine ramusa mandibule obavljeno je između točaka Condylion superior (Co) - najviše točke na mandibularnom kondilu i gonion (Go), kao što se može vidjeti na slici 1. D. A maksimalna dužina mandibule izmjerena je izmedu točaka condylion (Co) i pogonion $(\mathrm{Pg})$ - najanteriornije srednje točke brade prikazane na slici 1 . E.

Sve udaljenosti, osim gonijalnog kuta, izmjerene su digitalnom pomičnom mjerkom razlučivosti $0,1 \mathrm{~mm}$ i točnosti +/- 0,1 mm proizvođača Western ${ }^{\text {TM }}$ (Etilux ${ }^{\text {TM }}$, São Paulo, Brazil) koja prikazuje vrijednosti u milimetrima. Za određivanje gonijalnog kuta upotrijebljen je kutomjer od $180^{\circ}$ na takav način da je centar dotaknuo bazu mandibule, a oznaka stupnja bila je tangenta prema stražnjem rubu ramusa mandibule, čime je određena vrijednost kuta.

Mandibule su grupirane prema dobi: G1 $=0$ do 20 godina; $\mathrm{G} 2=21$ do 40 godina; $\mathrm{G} 3=41$ do 60 godina; $\mathrm{G} 4=61$ do 80 godina; G5 = 80 do 100 godina, bez obzira na spol. Veličina uzorka po skupini bila je: 4, 24, 29, 35 i 11 uzoraka.

$\mathrm{Za}$ statističku analizu primijenjena je jednosmjerna ANOVA s razinom značajnosti od $5 \%$ kako bi se provjerilo jesu li vrijednosti mjerenja mandibule bile povezane $s$ dobi. Studentov t-test primijenjen je za usporedbu uzoraka prema spolu. Ti su testovi izvedeni korištenjem softvera Graphpad Prism verzije 7.01 za Windowse (GraphPad ${ }^{\mathrm{TM}}$, La Jolla, Kalifornija, SAD). Oba su testa provedena na nesparenim uzorcima. Logistički regresijski model razvijen je s pomoću 83 nasumično odabrana uzorka, a zatim je 20 mjerenja korišteno za testiranje modela. Postupni automatski odabir korišten je za izbor najboljeg mjerenja za procjenu spola. Razlike unutar i između promatrača ocjenjivane su za svako mjerenje koje se provodilo na mandibulama s pomoću koeficijenta korelacije unutar klase (ICC) koristeći se kappa koeficijentom.

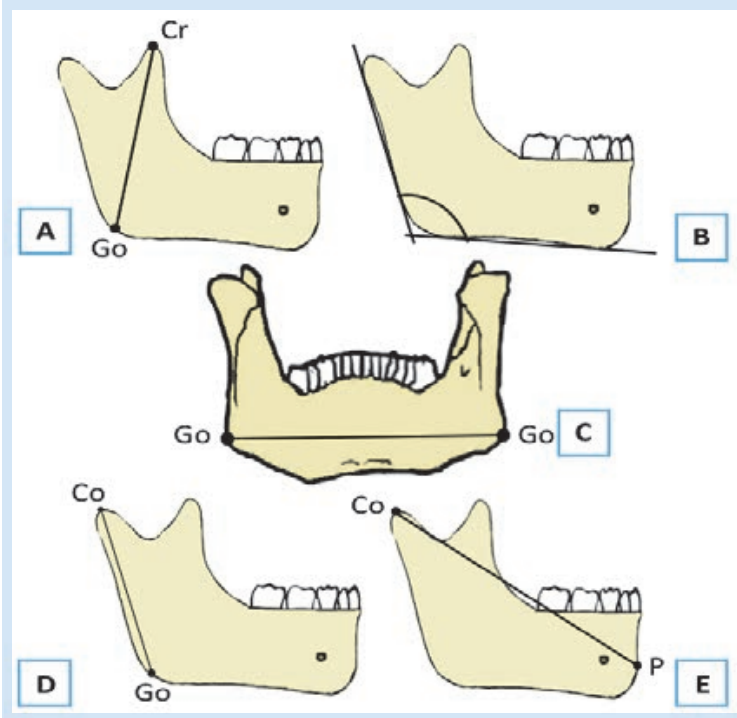

Figure 1 Didactic scheme for the measurements performed: (A) coronoid height measurement $(\mathrm{Cr}-\mathrm{Go})$; $(\mathrm{B})$ determination of the gonial angle (GA); (C) measurement of the bigonial distance (Go-Go); (D) measurement of ramus height (Co-Go); and (E) measurement of the mandible maximum length $(\mathrm{Co}-\mathrm{Pg})$.

Slika 1. Didaktička shema provedenih mjerenja: (A) mjerenje visine točke coronoid ( $\mathrm{Cr}-\mathrm{Go})$; (B) određivanje gonijalnog kuta (GA); (C) mjerenje bigonijalne udaljenosti (Go-Go); (D) mjerenje visine ramusa ( $\mathrm{Co}-\mathrm{Go})$; (E) mjerenje maksimalne duljine mandibule $(\mathrm{Co}-\mathrm{Pg})$ 


\section{Results}

The results for sex estimation are described in Table 1. All the measurements were statistically significant, since they had a value of $\mathrm{p} \leq 0.01$ and all of them were larger in men, except for the gonial angle (GA), which was larger in women.

All the variables were analyzed to develop the logistic regression formula, however, the following two variables were better sex predictors: bigonial distance and mandibular ramus. Because of that, those variables were chosen to compose the following logistic regression formula (Figure 2). If the value for sex from the model is higher than 0.5 , it is classified as male and if is lower than 0.5 , it is classified as female. The accuracy of the proposed model was $90 \%$.

The mandibles grouped according to age with the mean and respective standard deviation of each of the measurements can be better analyzed in Table 2 .

\section{Rezultati}

Rezultati procjene spola opisani su u tablici 1 . Sva mjerenja bila su statistički značajna $s$ vrijednostima $\mathrm{p} \leq 0,01$ i sve vrijednosti mjerenja bile su veće kod muškaraca, osim gonijalnog kuta (GA) koji je bio veći kod žena.

Sve su varijable analizirane kako bi se dobila formula logističke regresije, no sljedeće su varijable bile bolji prediktori spola: bigonijalna udaljenost i ramus mandibule. Zbog toga su izabrane za sastavljanje sljedeće logističke regresijske formule (slika 2.). Ako je vrijednost za spol iz modela bila veća od 0,5, uzorak je klasificiran kao muški, a ako je bila niža od 0,5 , klasificiran je kao ženski. Točnost predloženog modela bila je $90 \%$.

Mandibule grupirane prema dobi sa srednjim vrijednostima i odgovarajućim standardnim devijacijama svakog mjerenja mogu se bolje analizirati u tablici 2 .

Table 1 Range in millimeters, of the values found in the measurements to estimate the sex with the respective value of $p$.

Tablica 1. Raspon u milimetrima vrijednosti mjerenja za procjenu spola s odgovarajućom vrijednosti p.

\begin{tabular}{c|c|c|c}
\multirow{2}{*}{\begin{tabular}{c} 
Measurements $\bullet$ Mjerenje \\
\cline { 2 - 3 }
\end{tabular}} & \multicolumn{2}{c|}{$\begin{array}{c}\text { Range }(\mathbf{m m}) \bullet \text { Raspon }(\mathbf{m m}) \\
\text { Male } \bullet \text { Muško }\end{array}$} & Value of $\mathbf{p} \bullet$ Vrijednost $\mathbf{p}$ \\
\hline Co-Go & $45.88-62.4$ & $52.05-69.3$ & $<0.0001$ \\
\hline Cr-Go & $42.4-70.75$ & $51-69.75$ & $<0.0001$ \\
\hline GA & $118-140$ & $104-139.8$ & 0.0064 \\
\hline Go-Go & $81.65-94.9$ & $87.85-111.2$ & $<0.0001$ \\
\hline Co-Pg & $101.2-125.8$ & $112.6-129.7$ & $<0.0001$
\end{tabular}

Table 2 Mean and standard deviation of the values of the mandibular measurements for the age estimation.

Tablica 2. Srednja vrijednost i standardna devijacija odstupanja vrijednosti mjerenja mandibule za procjenu dobi

\begin{tabular}{c|c|c|c|c|c|c}
$\begin{array}{c}\text { Measurements } \\
\text { Mjerenje }\end{array}$ & \multicolumn{5}{|c|}{ Mean (Standard deviation) • Srednja vrijednost (standardna devijacija) } \\
Co-Go & $54.37(6.5)$ & G2 & $58.84(4.57)$ & $53.9(5.55)$ & $54.48(6.96)$ & $52.78(5.17)$ \\
\hline Cr-Go & $56.77(8.38)$ & $59.69(6.96)$ & $53.93(3.48)$ & $56.09(8.43)$ & $55.57(4.51)$ \\
\hline GA & $118.5(2,39)$ & $122.4(8.07)$ & $129.6(7.75)$ & $126.2(8.66)$ & $131.1(4.11)$ \\
\hline Go-Go & $83.68(5.07)$ & $94.11(6.45)$ & $91.7(6.40)$ & $94.53(8.16)$ & $89.72(6.53)$ \\
\hline Co-Pg & $109(8.17)$ & $119.1(4,93)$ & $117.7(7.32)$ & $116.9(6.60)$ & $116(7.27)$ \\
\hline
\end{tabular}

Table 3 Inter-observer and intra-observer correlation index.

Tablica 3. Indeks korelacije između i unutar promatrača

\begin{tabular}{c|c|c|c} 
Measurement $\bullet$ Mjerenje & $\begin{array}{c}\text { Inter-observer } \\
\text { Izmedu promatrača }\end{array}$ & $\begin{array}{c}\text { Intra-observer 1 } \\
\text { Unutar promatrača 1 }\end{array}$ & $\begin{array}{c}\text { Intra-observer 2 } \\
\text { Unutar promatrača 2 }\end{array}$ \\
\hline Co-Go & 0.93 & 0.89 & 0.94 \\
\hline Cr-Go & 0.92 & 0.97 & 0.99 \\
\hline GA & 0.89 & 0.97 & 0.97 \\
\hline Go-Go & 0.92 & 0.97 & 0.99 \\
\hline Co-Pg & 0.93 & 0.85 & 0.97 \\
\hline
\end{tabular}

Figure 2 Formula for sex estimation is developed using the following two measurements: bigonial distance and mandibular ramus. Values higher than 0.5 were classified as male, and if lower than 0.5 they were classified as female.

$\widehat{\text { Sexo }}=\frac{\exp ^{-24,3960+0,1525 * \text { bigonial distance }+0,1812 * \text { mandibular ramus }}}{1+\exp ^{-24,3960+0,1525 * \text { bigonial distance }+0,1812 * \text { mandibular ramus }}}$

Slika 2. Formula za procjenu spola dobivena je korištenjem sljedećih dvaju mjerenja: bigonijalne udaljenosti i ramusa mandibule. Vrijednosti veće od 0,5 klasificirane su kao muške, a niže od 0,5 kao ženske. 
Groups G2 and G3 did have a statistically significant difference between them in three variables: $\mathrm{Co}-\mathrm{Co}$; $\mathrm{Cr}-\mathrm{Go}$; GA, with value of $\mathrm{p} \leq 0.05$. Furthermore, it was observed that comparing the groups in the variable Co-Go, the G2 also had a statistically significant difference $(\mathrm{p} \leq 0.05)$ with $\mathrm{G} 3, \mathrm{G} 4$, G5. However, the groups G4 and G5 demonstrated a statistical relevance only regarding this variable. The measurements of bigonial distance (Go-Go) and maximum length of the mandible (Co-Pg), had no groups that were statistically relevant. There was an increase in the gonial angle (GA) in all the groups, except for G4, where there was a small decrease in value. The other measurements did not have an increase or decrease pattern in values from G1 to G5.

The agreement analysis of inter-observers had values greater than 0.89 , and the intra-observer agreement analysis had values ranging from 0.85 to 0.99 (Table 3).

\section{Discussion}

The methodology used is useful for sex estimation with high accuracy, especially the measurements of Go-Go and Co-Go. It was possible to create a logistic regression model using those measurements that presented 90\% accuracy for sex estimation in this sample. However, this methodology was not ideal for prediction the age; only Co-Go was effective for this purpose. The study had high values in the inter and intra-observer analysis, showing good accuracy in the measurements made for the same person or for more than one observer. This indicates that the methodology is reproductive, thus being useful in forensic cases.

There is a scientific consensus that males have measurements larger than females. This study shows that in mandibles measurements it is no different, therefore, agreeing with other cited authors (5-7,10,22-24). Gillet et al. (24), using a multislice computed tomography, found larger values for males than females. They concluded that the mandible is not the most dimorphic structure among other cephalic structures, but a useful tool when only this structure is available and not the entire skull. Another Brazilian study (7) was able to create discriminant functions with mandibular measurements, and they concluded that the mandible variables are important for sex estimation. However, GA is a very discrepant measurement, sometimes being larger in males $(5,7,22)$, other times in females $(11,12,23,25)$, which was the case in our study. Belaldavar et al. (25) used only the gonial angle for sexual dimorphism, and their values were higher for females, although the sex prediction with this measurement was low and not useful for forensic purposes. The gonial angle may be related to the size of the mandible, the smaller the ramus, more obtuse is the angle (18), thus explaining why we found higher values for females than males.

It was observed that bigonial distance and mandibular ramus were the most dimorphic variables, being able to develop one logistic regression model with $90 \%$ accuracy. Vodanovic et al. (10) using 18 mandible variables, found that the length of the mandibular body; mandibular angle; and a minimum ramus breadth provided the best separation of the sexes, thus disagreeing with our study. However, the accuracy in their
Skupine G2 i G3 imale su statistički značajnu razliku između triju varijabla: $\mathrm{Co}-\mathrm{Co}, \mathrm{CR}-\mathrm{Go}$ i GA, s vrijednošću $\mathrm{p} \leq 0,05$. Nadalje, uočeno je da je, uspoređujući skupine prema varijabli Co - Go, skupina G2 imala statistički značajnu razliku $(p \leq 0,05)$ u odnosu prema G3, G4, G5. No, skupine G4 i G5 pokazale su statističku značajnost samo u toj varijabli. Mjerenja bigonalne udaljenosti (Go - Go) i maksimalne dužine andibule (Co - Pg) ni u jednoj skupini nisu bile statistički značajne. U svim skupinama povećan je gonijalni kut (GA), osim u G4 gdje je zabilježen mali pad vrijednosti. Ostala mjerenja nisu imala obrazac povećanja ili smanjenja vrijednosti u skupinama od G1 do G5.

Analiza podudarnosti među promatračima imala je vrijednosti veće od 0,89 , a analiza podudarnosti unutar promatrača dala je vrijednosti od 0,85 do 0,99 (tablica 3.).

\section{Rasprava}

Primijenjena metoda korisna je za procjenu spola s velikom preciznošću, posebno za mjerenja Go - Go i Co - Go. Mogao se kreirati logistički regresijski model primjenom onih mjerenja koja su u ovom uzorku pokazala $90 \%$ točnosti pri procjeni spola. Međutim, ta metodologija nije bila idealna za predviđanje dobi; samo je Co - Go bio učinkovit u tu svrhu. $U$ istraživanju su dobivene visoke vrijednosti podudarnosti između i unutar promatrača, što upućuje na zadovoljavajuću točnost u mjerenjima i za pojedinca i za više od jednog promatrača. To pokazuje da je metodologija reproduktivna pa je korisna u forenzičke svrhe.

Postoji znanstveni konsenzus da su izmjerene vrijednosti kod muškaraca veće negoli kod žena. Ovo istraživanje pokazuje da se to u mjerenjima mandibule ne razlikuje, dakle, u skladu je s ostalim citiranim autorima $(5-7,10,22-24)$. Gillet i suradnici (24) utvrdili su veće vrijednosti za muškarce u odnosu prema ženama s pomoću višeslojne računalne tomografije. Zaključili su da mandibula nije najdimorfnija struktura među ostalim cefaličnim strukturama, nego je koristan alat kada je dostupna samo ona, a ne cijela lubanja. Autori jednoga drugog brazilskog istraživanja (7) uspjeli su stvoriti diskriminirajuće funkcije $s$ mjerenjima mandibule i zaključeno je da su varijable mandibule važne za procjenu spola. No GA je vrlo varijabilna mjera, katkad veća kod muškaraca $(5,7,22)$, katkad kod žena $(11,12,23,25)$, što je bio slučaj i u našem istraživanju. Belaldavar i suradnici (25) upotrijebili su samo gonijalni kut za spolni dimorfizam i njihove su vrijednosti bile veće za žene, iako je predviđanje spola s tim mjerenjem nisko i nije korisno za forenzičke svrhe. Gonijalni kut može biti povezan $s$ veličinom mandibule - što je manji ramus, točniji je kut (18), i objašnjava zašto smo utvrdili veće vrijednosti za žene negoli za muškarce.

Uočeno je da su bigonijalna udaljenost i mandibularni ramus najdimorfnije varijable, čime je dobiven logistički regresijski model s $90 \%$ točnosti. Vodanović i suradnici (10) su s pomoću 18 varijabli mandibule utvrdili da su dužina tijela mandibule, mandibularni kut i minimalna širina ramusa omogućili najbolje razlikovanje spolova, što se ne podudara s rezultatima našeg istraživanja. Međutim, koristeći se s 9 
study was $92.06 \%$ using 9 variables, value close to presented in this study (90\%), using only 2 variables. It is worth mentioning that Vodanovic et al. (10) observed that with less variables such as three or one, this accuracy is lower, $88.24 \%$ and $69.23 \%$ to $81.36 \%$ respectively.

In our study it was not possible to use the same size of samples in each age group, however, this was also the case in other studies $(17,19,26)$ and in those, it was considered effective for age estimation. Gonial angle showed to increase with age $(19,27)$, but another study found that this measurement decreases with age (26), which seems to be more logical, since the angle is inversely proportional with the measurement of the mandibular ramus which increases with age $(19,28)$. In this study, the bigonial distance did not have values with an increase or decrease pattern, agreeing with another study (17). However, because of the increase of the entire mandible with age, this measurement was supposed to grow as observed in other studies $(17,19)$. Regarding the mandible maximum length, it decreased with older age. Even though no pattern was found, Rajkumari et al. (23) were able to create a multiple linear regression to predict the age using mandible measurements, some of them similar to ours. This would be explained precisely by the fact that if the gonial angle decreases with age, the mandibular ramus will be closer to the mandibular mentum, thus making the mandible maximum length smaller.

When the intra and inter-observer evaluations were performed, all values were high, showing that the study could be reproduced by anyone. In contrast, Gamba et al. (22), despite using measurements that were the same or similar to those of the present study, found very contrasting values for intra and inter-observer evaluations. Their research, however, performed the measurements in computed tomography and not in bone pieces directly, with which can be inferred that it is better to perform measurements on bone structures rather than on images, even if those images are shown to be accurate.

One limitation found in this study was the sample: once it needed to be identified, having the correct sex and age and not just the estimation of those variables, we did not have many samples available to use. Because of that, it was not possible to have the same number of samples in age groups. This probably brings some complications to our results for age estimation. However, with a regular number of sample $(27,28)$ or with different size of samples in each group $(17,19,26)$, it was considered effective for age estimation, with high degree of accuracy (28).

\section{Conclusion}

It is difficult to estimate age and sex, which would be based on international measurements and methodologies in the Brazilian mixed population, since these methods are often based on European populations. It is important to develop specific formulas or to validate methodologies in Brazilian population, because it is normal in forensic practice to use some modified international methodologies, especially if they are metric ones. This research showed to be impor- varijabli, točnost u njihovu istraživanju iznosila je 92,06 \%, što je vrijednost slična onoj u ovom istraživanju (90 \%), a koristili smo se samo s dvjema varijablama. Vrijedno je spomenuti da su Vodanović i suradnici (10) primijetili da je s manje varijabli, poput tri ili jedne, ta točnost manja $88,24 \%$ i $69,23 \%$ do $81,36 \%$.

$\mathrm{U}$ našem istraživanju nije bilo moguće upotrijebiti istu veličinu uzorka u svakoj dobnoj skupini, no to je bio slučaj i u drugim istraživanjima $(17,19,26)$. Pokazalo se da se gonijalni kut povećava s godinama $(19,27)$, ali u jednom je drugom istraživanju istaknuto da se ta vrijednost smanjuje $s$ dobi (26), što se čini logičnijim jer je kut obrnuto proporcionalan mjeri mandibularnog ramusa koji se povećava s dobi $(19,28)$. U ovom istraživanju bigonijalna udaljenost nije imala obrazac povećanja ili smanjenja, što je u skladu s drugim istraživanjima (17). No s obzirom na rast cijele mandibule s godinama, ta bi vrijednost također trebala rasti, što je opaženo i u drugim istraživanjima $(17,19)$. Kad je riječ o maksimalnoj dužini mandibule, ona se smanjivala u starijoj dobi. Iako nije pronađen obrazac, Rajkumari i suradnici (23) uspjeli su stvoriti višestruku linearnu regresiju za predviđanje dobi mjerenjem mandibule od kojih su neka slična našima. To bi se objasnilo činjenicom da će se, ako se gonijalni kut $s$ godinama smanjuje, mandibularni ramus približiti mandibularnom mentumu, čime će se najveća dužina mandibule smanjiti.

Pri analizi podudarnosti unutar i između promatrača sve su vrijednosti bile visoke, što pokazuje da istraživanje može reproducirati bilo tko. Suprotno tomu, Gamba i suradnici (22), unatoč provođenju mjerenja koja su bila ista ili slična onima iz ovoga istraživanja, dobili su vrlo različite vrijednosti za vrjednovanja unutar i između promatrača. No u njihovu su se istraživanju mjerenja provodila s pomoću računalne tomografije, a ne izravno na kostima, iz čega se može izvesti zaključak da je bolje obavljati mjerenja na koštanim strukturama, a ne na slikama, čak ako se te slike pokažu točnima.

Ograničenje u ovom istraživanju bio je uzorak - nismo imali mnogo uzoraka s poznatim spolom i dobi. Zbog toga nije bilo moguće imati jednak broj uzoraka u svim dobnim skupinama. To vjerojatno dovodi do nekih komplikacija u našim rezultatima za procjenu dobi. No uz adekvatan broj uzoraka $(27,28)$, ili s različitom veličinom uzorka u svakoj skupini $(17,19,26)$ metoda bi se mogla smatrati učinkovitom za procjenu dobi, s visokim stupnjem točnosti (28).

\section{Zaključak}

Teško je procijeniti dob i spol na temelju međunarodnih mjera i metodologijama u mješovitoj populaciji Brazila, jer se te metode često temelje na europskoj populaciji. Važno je razviti određene formule ili potvrditi metodologije na brazilskoj populaciji s obzirom na to da je u forenzičkoj praksi normalno upotrebljavati neke modificirane međunarodne metodologije, pogotovo ako su metričke. Ovo se istraživanje pokazalo važnim jer je dobivena formula za procjenu spola na 
tant, since the developed formula for sex estimation in Brazilian presented $90 \%$ accuracy, hence it is possible to estimate sex using mandibular measurements. However, the age estimation does not follow a pattern between the groups, therefore it is not recommended to use only these measurements for this purpose.

\section{Conflict of interest}

$$
\text { None declared }
$$

\section{Contribution to the paper}

J.G.D.P., K.F.L.: acquisition of data; analysis and/or interpretation of data; drafting the manuscript; R.H.A.S.: conception and design of study; supervision of the study; revising the manuscript critically for important intellectual content brazilskoj populaciji s 90-postotnom točnošću. Zato je moguće procijeniti spol koristeći se mjerenjem mandibule. No procjena dobi ne slijedi obrazac između skupina i zato se ne preporučuje upotrebljavati samo ta mjerenja u tu svrhu.

\section{Sukob interesa}

Nije naveden.

\section{Doprinos autora u radu:}

J. G. D. P., K. F. L. - prikupljanje podataka; analiza i/ili interpretacija podataka; sastavljanje rukopisa; R. H. A. S. koncepcija i dizajn istraživanja; nadzor istraživanja; revizija rukopisa važna za intelektualni sadržaj
Sažetak

Svrha rada: Cilj ovog istraživanja bio je ispitati mogućnost procjene spola i dobi na brazilskom uzorku na temelju sljedećih pet mjera na mandibuli: visine koronoida, gonijalnog kuta, bigonijalne udaljenosti, visine ramusa i maksimalne dužine. Materijal i metode: Ukupno su izmjerene 103 donje čeljusti - 53 ženskih i 50 muških, a bile su grupirane prema dobi u pet različitih skupina. Sva mjerenja obavila su dva promatrača. Za statističku analizu korištena je jednosmjerna ANOVA s razinom značajnosti od $5 \%$ kako bi se provjerilo jesu li vrijednosti mjerenja mandibule povezane s dobi. Studentov t-test upotrijebljen je za usporedbu uzoraka spola. Osamdeset tri uzorka korištena su za izradu modela logističke regresije. Razlike unutar i između promatrača ocijenjene su kappa koeficijentom. Rezultati: Razlike u spolu bile su statistički značajne u svim varijablama, a sve vrijednosti bile su veće kod muškaraca, osim varijable koja se odnosila na gonijalni kut (GA) koji je bio veći kod žena. Za formulu logističke regresije upotrijebljene su varijable: bigonijalna udaljenost i mandibularni ramus, s 90-postotnom točnošću. Za dob mjerenja nisu pokazala određeni obrazac. Vrijednosti unutar i između promatrača bile su veće od 0,85 . Zaključak: Zaključeno je da se mjerenjem mandibule može procijeniti spol, ali ne preporučuje se upotrijebiti ta mjerenja za procjenu dobi.
Zaprimljen: 10. travnja 2020. Prihvaćen: 3. srpnja 2020.

Adresa za dopisivanje Julia Gabriela Dietrichkeit Pereira Sveučilište São Paulo, Medicinsk fakultet

Ribeirão Preto, Brazil telefon: +55 (19) 984060244 juliadie@usp.br

Ključne riječi

forenzička stomatologija, određivanje spola s pomoću skeleta, određivanje dobi s pomoću kostura, donja čeljust, mjerenja

\section{References}

1. MeSH Browser [database on the Internet]. Vanezis $P$, Blowes RW, Linney AD, Tan AC, Richards R, Neave R. Application of 3-D computer graphics for facial reconstruction and comparison with sculpting techniques. Forensic Sci Int. 1989 Jul;42(1-2):6984. Available from: http://linkinghub.elsevier.com/retrieve/ pii/0379073889902004

2. De Greef S, Willems G. Three-dimensional cranio-facial reconstruction in forensic identification: latest progress and new tendencies in the 21st century. J Forensic Sci. 2005 Jan;50(1):12-7.

3. Popa FM, Ştefănescu CL, Corici PD. Forensic value of mandibular anthropometry in gender and age estimation. Rom J Leg Med. 2009;17(1):45-50.

4. MeSH Browser [database on the Internet]. Saini V, Srivastava R, Shamal SN, Singh TB, Pandey AK, Tripathi SK. Sex determination using mandibular ramus flexure: A preliminary study on Indian population. J Forensic Leg Med. 2011 Jul;18(5):208-12. Available from: http://dx.doi.org/10.1016/j.jflm.2011.02.014

5. MeSH Browser [database on the Internet]. Damera A, Mohanalakhsmi J, Yellarthi P, Rezwana B. Radiographic evaluation of mandibular ramus for gender estimation: Retrospective study. J Forensic Dent Sci. 2016;8(2):74. Available from: http://www.jfds. org/text.asp?2016/8/2/74/186369

6. MeSH Browser [database on the Internet]. Alias A, Ibrahim A, Abu Bakar SN, Swarhib Shafie M, Das S, Abdullah N, et al. Anthropometric analysis of mandible: an important step for sex determination. Clin Ter [Internet]. 169(5):e217-23. Available from: http:// www.ncbi.nlm.nih.gov/pubmed/30393808

7. MeSH Browser [database on the Internet]. Lopez-Capp TT, Rynn C, Wilkinson C, de Paiva LAS, Michel-Crosato E, Biazevic MGH. Discriminant analysis of mandibular measurements for the esti mation of sex in a modern Brazilian sample. Int J Legal Med. 2018 May 26;132(3):843-51. Available from: http://link.springer. com/10.1007/s00414-017-1681-8
8. MeSH Browser [database on the Internet]. Satish BNVS, Moolrajani $C$, Basnaker $M$, Kumar $P$. Dental sex dimorphism: Using odontometrics and digital jaw radiography. J Forensic Dent Sci. 2017;9(1):43. Available from: http://www.ncbi.nlm.nih.gov/ pubmed/28584477

9. Deana NF, Alves N. Nonmetrical sexual dimorphism in mandibles of Brazilian individuals. Biomed Res. 2017;28(9):4233-8.

10. Vodanović M, Dumančić J, Demo Ž, Mihelić D. Determination of sex by discriminant function analysis of mandibles from two Croatian archaeological sites. Acta Stomatol Croat. 2006;40(3):26377.

11. MeSH Browser [database on the Internet]. Sharma M, Gorea RK, Gorea A, Abuderman A. A morphometric study of the human mandible in the Indian population for sex determination. Egypt J Forensic Sci. 2016;6(2):165-9. Available from: http://dx.doi. org/10.1016/j.ejfs.2015.01.002

12. Tunis TS, Sarig R, Cohen H, Medlej B, Peled N, May H. Sex estimation using computed tomography of the mandible. Int J Legal Med. 2017 Nov;131(6):1691-1700.

13. MeSH Browser [database on the Internet]. Bayrak S, Halıcıoglu $\mathrm{S}$, Kose G, Halıcıoglu K. Evaluation of the relationship between mandibular condyle cortication and chronologic age with cone beam computed tomography. J Forensic Leg Med. 2018 Apr;55(November 2017):39-44. Available from: https://linkinghub.elsevier.com/retrieve/pii/S1752928X18300301

14. MeSH Browser [database on the Internet]. Birchler FA, Kiliaridis S, Combescure C, Vazquez L. Dental age assessment on panoramic radiographs in a Swiss population: a validation study of two prediction models. Dentomaxillofacial Radiol. 2016 Jan;45(1):20150137. Available from: http://www.birpublications.org/doi/10.1259/dmfr.20150137

15. Puneeth H, Nandini D, Praveen S, Selvamani M, Mandana D. A Comparative Study of Efficacy of Single Rooted and Double Root- 
ed Teeth in Age Estimation Using Dentin Translucency. J Forensic Odontostomatol. 2016 Dec 1;34(2):1-10.

16. MeSH Browser [database on the Internet]. Kumagai A, Willems G, Franco A, Thevissen P. Age estimation combining radiographic information of two dental and four skeletal predictors in children and subadults. Int J Legal Med. 2018 Nov 11;132(6):1769-77. Available from: http://link.springer.com/10.1007/s00414-0181910-9

17. MeSH Browser [database on the Internet]. Bhuyan R, Mohanty S, Bhuyan S, Pati A, Priyadarshini S, Das P. Panoramic radiograph as a forensic aid in age and gender estimation: Preliminary retrospective study. J Oral Maxillofac Pathol. 2018;22(2):266. Available from: http://www.jomfp.in/text.asp?2018/22/2/266/238300

18. Jensen E, Palling M, editors. The gonial angle. In: American Journal of Orthodontics. 1954. p. 120-33.

19. Al-Shamout R, Ammoush M, Alrbata R, Al-Habahbah A. Age and gender differences in gonial angle, ramus height and bigonial width in dentate subjects. Pakistan Oral Dent J. 2012;32(1):81-7.

20. MeSH Browser [database on the Internet]. Brasil. Ministério da Saúde, Conselho Nacional de Saúde. Resolução no 466 de 12 de dezembro de 2012, Diário Oficial da União n 1213 de junho de 2013-Seção 1, Pág 59. Available from: http://conselho.saude. gov.br/resolucoes/2012/Reso466.pdf

21. White TD, Black MT, Folkens PA, editors. Skull: Cranium and Mandible. In: Human Osteology. 3rd ed. Academic Pres; 2011. p. 688.

22. Gamba TDO, Alves MC, Haiter-Neto F. Mandibular sexual dimorphism analysis in CBCT scans. J Forensic Leg Med. 2016;38:10610.
23. MeSH Browser [database on the Internet]. Rajkumari S, Nikitha K, Monisha S, Nishagrade S, Thayumanavan B, Murali B. Role of Orthopantamograph in Forensic Identification: A Retrospec tive Study Among Chennai Population. J Pharm Bioallied Sci. 2019;11(6):393. Available from: http://www.jpbsonline.org/ text.asp?2019/11/6/393/258874

24. Gillet C, Costa-Mendes L, Rérolle C, Telmon N, Maret D, Savall F. Sex estimation in the cranium and mandible: a multislice computed tomography (MSCT) study using anthropometric and geometric morphometry methods. Int J Legal Med. 2020 Mar;134(2):823832

25. Belaldavar C, Acharya AB, Angadi P. Sex estimation in Indians by digital analysis of the gonial angle on lateral cephalographs. J Forensic Odontostomatol. 2019 Sep 30;37(2):45-50.

26. MeSH Browser [database on the Internet]. Ashkenazi M, Taubman L, Gavish A. Age-Associated changes of the mandibular foramen position in anteroposterior dimension and of the mandibular angle in dry human mandibles. Anat Rec Adv Integr Anat Evol Biol. 2011 Aug;294(8):1319-25. Available from: http://doi.wiley. com/10.1002/ar.21429

27. Mohite DP, Chaudhary MS, Mohite PM, Patil SP. Age assessment from mandible: Comparison of radiographic and histologic methods. Rom J Morphol Embryol. 2011;52(2):659-68.

28. MeSH Browser [database on the Internet]. Oliveira FT de, Soares MQS, Sarmento VA, Rubira CMF, Lauris JRP, Rubira-Bullen IRF. Mandibular ramus length as an indicator of chronological age and sex. Int J Legal Med. 2015 Jan 1;129(1):195-201. Available from: http://link.springer.com/10.1007/s00414-014-1077-y 